\title{
Microstructure, mechanical properties and chemical degradation of brazed AISI 316 stainless steel/alumina systems
}

\author{
O.C. Paiva, M.A. Barbosa
}

\begin{abstract}
The main aims of the present study are simultaneously to relate the brazing parameters with: (i) the correspondent interfacial microstructure, (ii) the resultant mechanical properties and (iii) the electrochemical degradation behaviour of AISI 316 stainless steel/alumina brazed joints. Filler metals on such as $\mathrm{Ag}-26.5 \mathrm{Cu}-3 \mathrm{Ti}$ and $\mathrm{Ag}-34.5 \mathrm{Cu}-1.5 \mathrm{Ti}$ were used to produce the joints. Three different brazing temperatures $(850,900$ and $950{ }^{\circ} \mathrm{C}$ ), keeping a constant holding time of $20 \mathrm{~min}$, were tested. The objective was to understand the influence of the brazing temperature on the final microstructure and properties of the joints. The mechanical properties of the metal/ceramic (M/C) joints were assessed from bond strength tests carried out using a shear solicitation loading scheme. The fracture surfaces were studied both morphologically and structurally using scanning electron microscopy (SEM), energy dispersive spectroscopy (EDS) and X-ray diffraction analysis (XRD). The degradation behaviour of the M/C joints was assessed by means of electrochemical techniques.

It was found that using a $\mathrm{Ag}-26.5 \mathrm{Cu}-3 \mathrm{Ti}$ brazing alloy and a brazing temperature of $850{ }^{\circ} \mathrm{C}$, produces the best results in terms of bond strength, $234 \pm 18 \mathrm{MPa}$. The mechanical properties obtained could be explained on the basis of the different compounds identified on the fracture surfaces by XRD. On the other hand, the use of the $\mathrm{Ag}-34.5 \mathrm{Cu}-1.5 \mathrm{Ti}$ brazing alloy and a brazing temperature of $850^{\circ} \mathrm{C}$ produces the best results in terms of corrosion rates (lower corrosion current density), $0.76 \pm 0.21 \mu \mathrm{A} \mathrm{cm}^{-2}$. Nevertheless, the joints produced at $850{ }^{\circ} \mathrm{C}$ using a $\mathrm{Ag}-26.5 \mathrm{Cu}-3 \mathrm{Ti}$ brazing alloy present the best compromise between mechanical properties and degradation behaviour, $234 \pm 18 \mathrm{MPa}^{\mathrm{and}} 1.26 \pm 0.58 \mu \mathrm{Acm} \mathrm{c}^{-2}$, respectively. The role of Ti diffusion is fundamental in terms of the final value achieved for the M/C bond strength. On the contrary, the Ag and $\mathrm{Cu}$ distribution along the brazed interface seem to play the most relevant role in the metal/ceramic joints electrochemical performance.
\end{abstract}

Keywords: Metal/ceramic joining; Active metal brazing; Shear strength; Electrochemical degradation; Processing parameters; Interface composition

\section{Introduction}

The joining of advanced ceramics to metals is of major interest for various industrial applications. Brazing with active filler alloys containing some active elements, which promotes wetting of ceramics surfaces, is one of the most widely methods for joining ceramics to metals $[1,2]$. One of the most widely used filler metal is based on the $\mathrm{Ag}-\mathrm{Cu}-\mathrm{Ti}$ system, namely on the $\mathrm{Ag}-28 \mathrm{Cu}$ eutectic composition, with about $2-5 \%$ of titanium additions [3-5]. This low level of alloying does not destroy the ductile nature of the solid eutectic or its fluidity when molten, but it is sufficient to ensure a high titanium activity [2,6] and permits to obtain metal/ceramic (M/C) joints without microstructural undesirable features at the interface such as cracks, unbonded areas and intermediate reaction layers.

Ideally if one can obtain a $\mathrm{M} / \mathrm{C}$ joint with a good mechanical performance that joint should be able to be safely used even in more traditional and less demanding engineering applications. However, some applications require utilisation under severe corrosive environments. Two examples of those are high efficiency heat exchangers [2], and the packaging of telemetric systems to be used in temporary implants [7-9].

It is well known that ceramics and some metals with industrial applications present per se are good combination of mechanical properties and resistance to corrosion. However, when ceramics and metals are together, special care should be taken in selecting the materials as well as the joining technique. This is especially 
true if the $\mathrm{M} / \mathrm{C}$ joint is aimed to work under a corrosive environment. On those cases it is needed that both the joining process and the produced interface do not compromise the $\mathrm{M} / \mathrm{C}$ corrosion resistance. This means that it is necessary to carry out corrosion studies in order to understand and predict the behaviour of the $\mathrm{M} / \mathrm{C}$ joints when in service. Nevertheless, the available studies on the corrosion of metal/ceramic joints are quite limited [7,9-12]. Some studies in this field present results emphasising the brazing filler metal and the metallic substrate electrochemical behaviour per se $[13,14]$, or the oxidation of brazing alloys at high temperatures [15]. However, no data is referred relatively to the $\mathrm{M} / \mathrm{C}$ brazed joints behaviour in aqueous corrosion media.

In this study AISI 316 stainless steel/ $\mathrm{Al}_{2} \mathrm{O}_{3}\left(316 / \mathrm{Al}_{2} \mathrm{O}_{3}\right)$ brazed joints were produced, by using active filler metals in the $\mathrm{Ag}-\mathrm{Cu}-\mathrm{Ti}$ system. The aims of the work are to show the need for the implementation of $\mathrm{M} / \mathrm{C}$ joints degradation studies when characterizing this type of $\mathrm{M} / \mathrm{C}$ joints. The degradation behaviour of the M/C joints was assessed by means of electrochemical techniques, namely the measurement of the corrosion potential as a function of time and potentiodynamic polarisation experiments. The paper also tries to relate those results with the respective microstructures and attained bond strength.

\section{Experimental procedure}

The metals and ceramics selected to produce the studied M/C joints were: AISI 316 stainless steel (316) (Ferespe, Portugal) and alumina $\left(\mathrm{Al}_{2} \mathrm{O}_{3}\right)$ (Degussa, Germany) $99.6 \%$ of purity. The brazing was carried out using two different brazing filler metals (Frialit-Degussa, Germany), in the shape of foils with $100 \mu \mathrm{m}$ of thickness: Ag-26.5Cu-3Ti (CB4) and Ag-34.5Cu-1.5Ti (CB5).

Before joining, the surfaces of the materials to be brazed were mechanically polished with a silicon carbide abrasive paper until 1200 mesh, and then ultrasonically cleaned in acetone, which was followed by rinsing in distilled water. The M/C joints were produced at a vacuum level of $10^{-2} \mathrm{~Pa}$ at three different temperatures, 850,900 and $950{ }^{\circ} \mathrm{C}$, using a constant holding time of $20 \mathrm{~min}$. The optimised heating and cooling rates were respectively 5 and $1.2^{\circ} \mathrm{C} \mathrm{min}^{-1}$.

Microstructural characterisation of the interfaces was carried out by scanning electron microscopy (SEM) using a Jeol JMS$6301 \mathrm{~F}$ microscope equipped with a Noran Instruments energy dispersive spectroscopy (EDS) device, both on cross-sections and fracture surfaces.

The bonding strength of the M/C joints was evaluated by using a shear fracture test described elsewhere [7]. The samples consisted of one piece of metal with $10 \mathrm{~mm}$ of thickness and $13.6 \mathrm{~mm}$ of diameter and one piece of ceramic with $5 \mathrm{~mm}$ of thickness and diameter, with a brazing alloy foil in between. In a universal mechanical testing machine, Lloyd Instruments LR $30 \mathrm{~K}$, the samples were tested at a cross-head speed of $0.5 \mathrm{~mm} \mathrm{~min}^{-1}$, applying a load in the ceramic part at a distance of $0.2 \mathrm{~mm}$ from the interface. For each joint/temperature condition at least six samples were tested. X-ray diffraction analysis (XRD) of the fracture surfaces was used to identify the reaction products. The XRD studies were performed in a Siemens D-5000 $\mathrm{X}$-ray diffractometer. Peak search databases and DOS-Diffract-
Table 1

Chemical composition of Hank's solution

\begin{tabular}{|c|c|}
\hline Chemical compound & Concentration $\left(\mathrm{g} / \mathrm{dm}^{3}\right)$ \\
\hline $\mathrm{CaCl}_{2} \cdot 2 \mathrm{H}_{2} \mathrm{O}$ & 0.185 \\
\hline $\mathrm{KCl}$ & 0.40 \\
\hline $\mathrm{KH}_{2} \mathrm{PO}$ & 0.60 \\
\hline $\mathrm{MgCl}_{2} \cdot 6 \mathrm{H}_{2} \mathrm{O}$ & 0.10 \\
\hline $\mathrm{MgSO}_{4} \cdot 7 \mathrm{H}_{2} \mathrm{O}$ & 0.10 \\
\hline $\mathrm{NaCl}$ & 8.00 \\
\hline $\mathrm{CaHCO}_{3}$ & 0.35 \\
\hline $\mathrm{NaHPO}_{4}$ & 0.48 \\
\hline D-Glucose & 1.00 \\
\hline
\end{tabular}

$\mathrm{AT}^{\circledR}$ software were also used. Tests were performed with $\mathrm{Cu}$ $\mathrm{K} \alpha$ radiation at $(40 \mathrm{kV} ; 30 \mathrm{~mA})$, using a graphite monochromator and a copper anode. The $2 \theta$ angles were scanned from $15^{\circ}$ to $90^{\circ}$, at a $0.02^{\circ} \mathrm{min}^{-1}$ scanning rate. All XRD analyses were carried out with a sample rotation of $60 \mathrm{rpm}$ in order to eliminate any eventual sample positioning or texture effect.

Furthermore, the degradation behaviour of the interface was assessed by means of electrochemical techniques. These tests were performed on cross-sections of $316 / \mathrm{Al}_{2} \mathrm{O}_{3}$ interfaces and for each joint/brazing temperature condition at least three samples were tested. The experimental programme includes the measurement of the corrosion potential as a function of time $\left(E_{\mathrm{corr}}\right)$ and potentiodynamic polarisation experiments. As, indicated in a previous work [7,9] these joints have been considered for encapsulating telemetric devices to be used on the monitoring of orthopaedic devices. The selected degradation media was therefore a saline solution, the Hank's balanced solution (HBSS) whose composition is presented in Table 1. All tests were conducted at $37 \pm 2{ }^{\circ} \mathrm{C}$ (physiological body temperature) and the potentials were measured against the saturated calomel electrode (SCE). Initially the specimens were immersed in the solution and their corrosion potentials were monitored for at least $60 \mathrm{~min}$ via a potentiostat/galvanostat (EG\&G Par, model 273-A). The potentiodynamic polarisations were carried out using the same equipment. The polarisation potential was scanned from -500 to $2000 \mathrm{mV}$ relatively to the saturated calomel electrode, using a polarisation scanning rate of $2 \mathrm{mV} \mathrm{min}^{-1}$. The corrosion current density was calculated using the well known Stern-Geary equation [16].

\section{Results and discussion}

\subsection{Microstructures}

Figs. 1 and 2 present cross-sections of $316 / \mathrm{CB} 4 / \mathrm{Al}_{2} \mathrm{O}_{3}$ and $316 / \mathrm{CB} 5 / \mathrm{Al}_{2} \mathrm{O}_{3}$ joints microstructures and some $\mathrm{X}$-ray elements distribution maps ( $\mathrm{Ti} \mathrm{K} \alpha, \mathrm{Fe} \mathrm{K} \alpha$ and $\mathrm{Cu} \mathrm{K} \alpha$ ) of joints produced at several brazing temperatures and a holding time of $20 \mathrm{~min}$. With both brazing alloys one could obtain $\mathrm{M} / \mathrm{C}$ joints free of defects. The microstructures are similar for both brazing alloys. The joints are basically composed of three different zones: (1) the interface between the brazing alloy and alumina $\left(\mathrm{CB} 4\right.$ or $\mathrm{CB} 5 / \mathrm{Al}_{2} \mathrm{O}_{3}$ ) called reaction layer, (2) a central zone composed for the brazing elements and diffusion elements from 

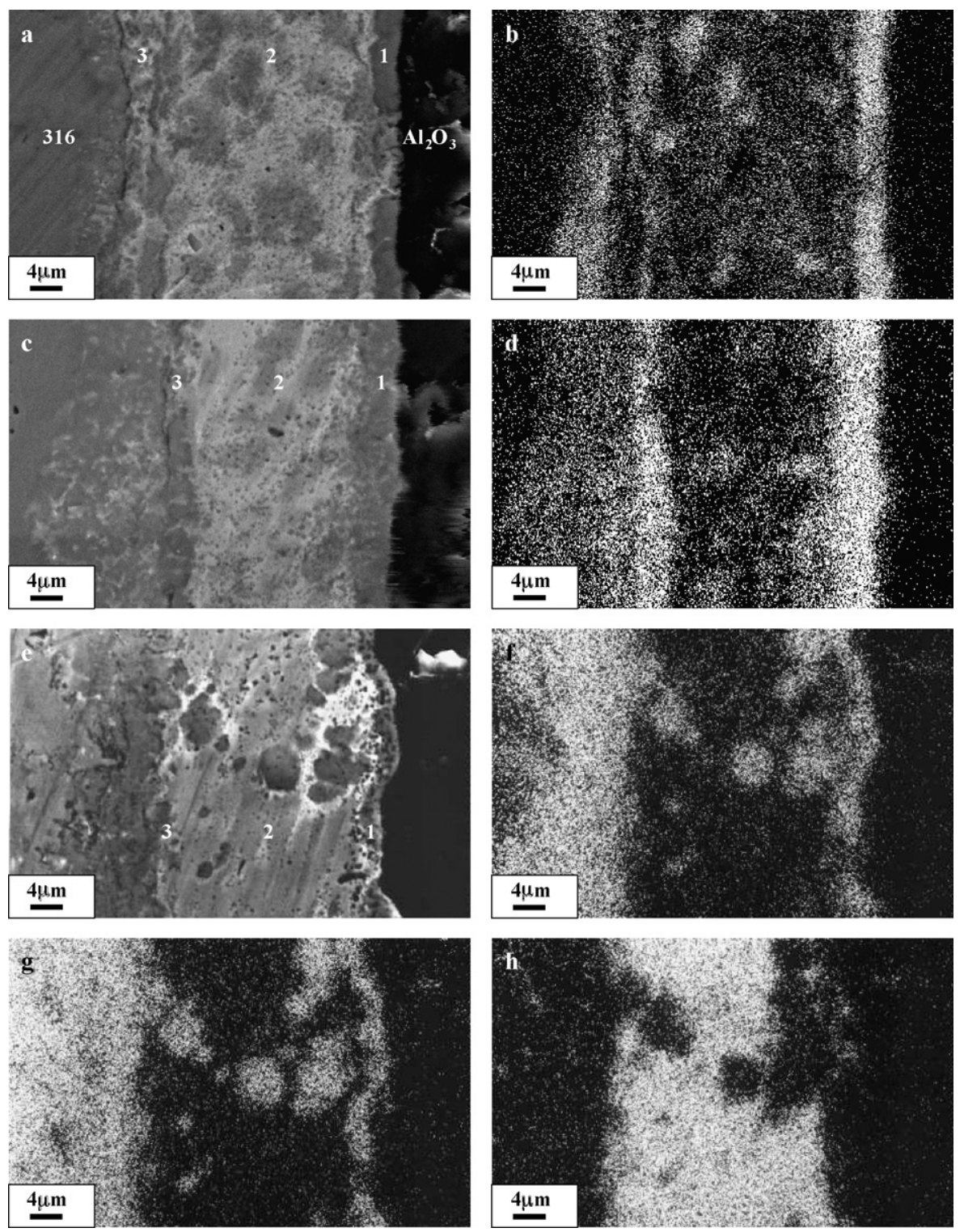

Fig. 1. Microstructures and X-ray elements distribution maps of $316 / \mathrm{CB} 4 / \mathrm{Al}_{2} \mathrm{O}_{3}$ joints produced at: (a) $850{ }^{\circ} \mathrm{C}$, (b) $\mathrm{Ti} \mathrm{X}$-ray map of joint (a), (c) $900{ }^{\circ} \mathrm{C}$, (d) $\mathrm{Ti} \mathrm{X}$-ray map of joint (c), (e) $950^{\circ} \mathrm{C}$, (f) Ti X-ray map of joint (e), (g) Fe X-ray map of joint (e) and (h) Cu X-ray map of joint (e).

316 and (3) the interface formed between the 316 and the brazing alloys (316/CB4 or CB5). For each system, $316 / \mathrm{CB} 4 / \mathrm{Al}_{2} \mathrm{O}_{3}$ and $316 / \mathrm{CB} 5 / \mathrm{Al}_{2} \mathrm{O}_{3}$, the most important interfacial zone, in terms of joint mechanical behaviour is the reaction layer, its chemical composition and thickness, two proprieties dependent on the brazing temperature as it is possible to observe in Figs. 1 and 2.

By means of analysing the 316/CB4 (Ag-26.5Cu-3Ti)/ $\mathrm{Al}_{2} \mathrm{O}_{3}$ joints it is possible to observe that the Ti diffuses from the brazing alloy to 316 and alumina surfaces as function of the brazing temperature. For $950^{\circ} \mathrm{C}$ the amount of Ti detected on 316/CB4 interface is higher than the amount detected at $\mathrm{CB} 4 / \mathrm{Al}_{2} \mathrm{O}_{3}$ interface attaining a distance around $20-25 \mu \mathrm{m}$ from 316 surfaces. The microstructures and the respective Xray $\mathrm{Ti} \mathrm{K} \alpha$ maps presented in Fig. 1 illustrate that. In all joints the reaction layer (zone 1) is very well defined and its chemical composition is mainly $\mathrm{Ti}, \mathrm{Cu}$, and some elements from the stainless steel, $\mathrm{Fe}, \mathrm{Ni}$ and $\mathrm{Cr}$. The zone 2 is basically composed by an $\mathrm{Ag}$ matrix (white areas) with $\mathrm{Cu}$ globules and some $\mathrm{Ti}$ disperses in this matrix. In the case of joints produced at $950{ }^{\circ} \mathrm{C}$ the morphology is replaced by large areas of $\mathrm{Cu}$ (see Fig. 1h) and the Ag is reduced to small white areas involving dark globules mainly composed by $\mathrm{Ti}$ and Fe (see Fig. If and g). The interface $316 / \mathrm{CB} 4$, zone 3 , is composed by stainless steel elements, $\mathrm{Fe}, \mathrm{Cr}$, Ni and $\mathrm{Mo}$, and brazing elements, $\mathrm{Ti}, \mathrm{Cu}$ and $\mathrm{Ag}$, the Ti amount present in this interface increase with the brazing temperature increase.

When analysing the microstructures of $316 / \mathrm{CB} 5 / \mathrm{Al}_{2} \mathrm{O}_{3}$ joints and respective Ti K $\alpha$ distribution maps presented in Fig. 2, one can conclude that they present morphologies similar to the joints produced with the brazing alloy CB4, although there are clear differences on the chemical composition between the two different brazing alloys (CB5 is richer in $\mathrm{Cu}, 34.5 \%$ and poor in reactive element $1.5 \% \mathrm{Ti}$ ). It is possible to divide the joints in the same three zones observed in the joints produced with CB4. 

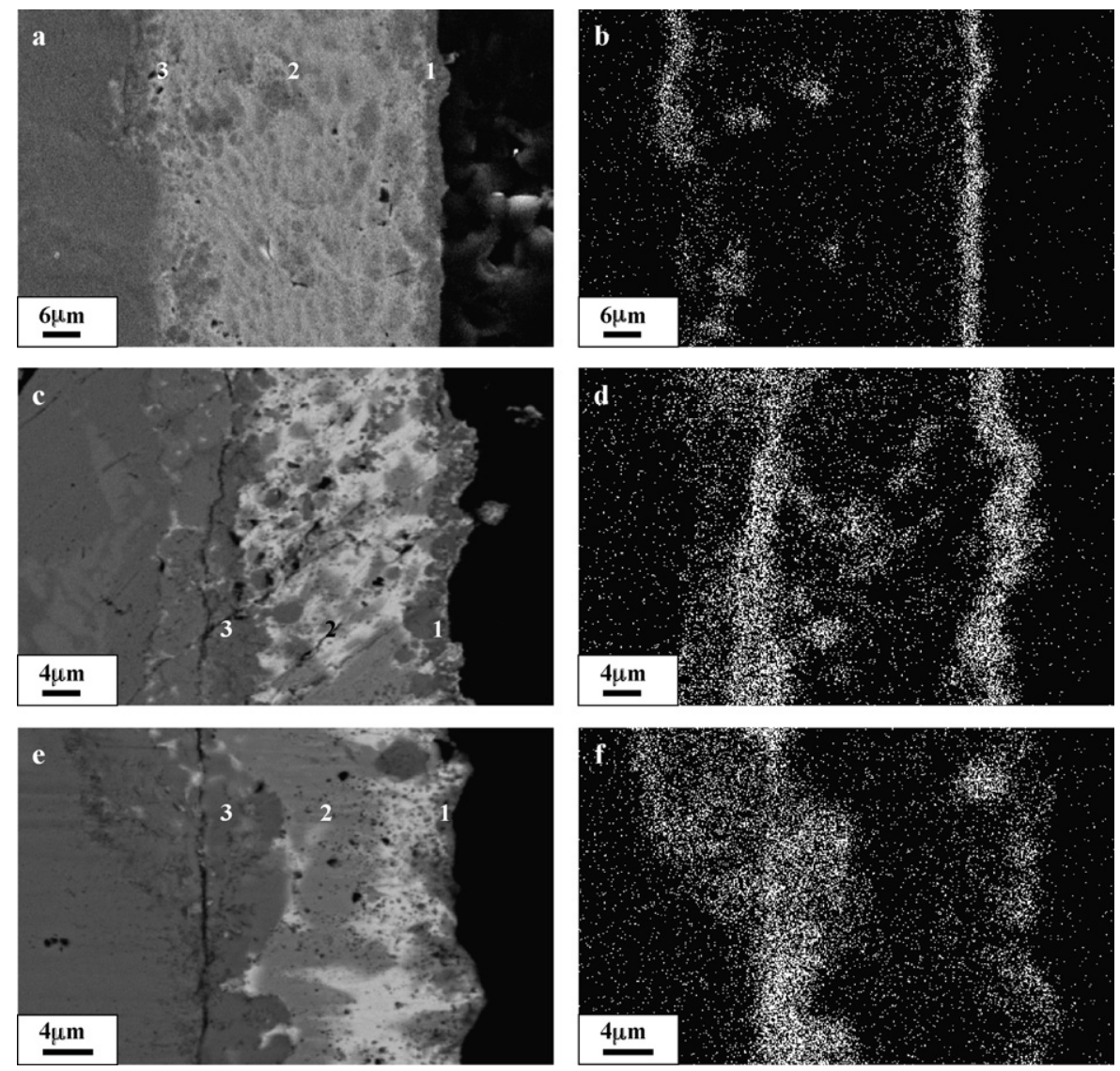

Fig. 2. Microstructures and X-ray elements distribution maps of $316 / \mathrm{CB} 5 / \mathrm{Al}_{2} \mathrm{O}_{3}$ joints produced at: (a) $850^{\circ} \mathrm{C}$, (b) Ti X-ray map of joint (a), (c) $900{ }^{\circ} \mathrm{C}$, (d) $\mathrm{Ti} \mathrm{X}$-ray map of joint (c), (e) $950^{\circ} \mathrm{C}$ and (f) Ti X-ray map of joint (e).

The interface $\mathrm{CB} 5 / \mathrm{Al}_{2} \mathrm{O}_{3}$ (zone 1), called the reaction layer, is composed by $\mathrm{Ti}, \mathrm{Cu}, \mathrm{Ag}$, and $\mathrm{Fe}, \mathrm{Cr}, \mathrm{Ni}$ (diffusion from stainless steel) and Al. A central zone (2) presenting different morphologies depending from the brazing temperature. For $850^{\circ} \mathrm{C}$ (see Fig. 2a) the zone 2 is composed by a $\mathrm{Cu}$ globules dispersed on an $\mathrm{Ag}$ matrix and by an almost random concentration of $\mathrm{Ti}$ as it can see in (Fig. 2b). For $900^{\circ} \mathrm{C}$ (Fig. 2c) it occurs some degree of concentration of $\mathrm{Cu}$ globules and the Ti distribution is more random (Fig. 2d). For $950^{\circ} \mathrm{C}$, the zone 2 is decomposed in two layers, the first (white) is composed essentially of $\mathrm{Ag}$ and the second is composed of $\mathrm{Cu}$ and $\mathrm{Ti}$. In the last layer it was also detected $\mathrm{Fe}$ and very low amounts of $\mathrm{Ni}$ and $\mathrm{Cr}$. The zone 3, the interface $316 / \mathrm{CB} 5$, is composed of the stainless steel elements and $\mathrm{Cu}$ (until 10 at\%) and $\mathrm{Ti}$ (until 25 at\%) as it possible to observe the Ti K $\alpha$ distribution map (Fig. 2f).

The composition of the reaction layers is the fundamental part of the joint in determining there mechanical behaviour. The joints $316 / \mathrm{CB} 4 / \mathrm{Al}_{2} \mathrm{O}_{3}$ and $316 / \mathrm{CB} 5 / \mathrm{Al}_{2} \mathrm{O}_{3}$ present a quite different evolution for the reaction layer thickness and its chemical composition as it is possible to observe in Figs. 3 and 4. With the increase of brazing temperature, the amount of $\mathrm{Ti}$ in the $\mathrm{CB} 4 / \mathrm{Al}_{2} \mathrm{O}_{3}$ interface increases until $900^{\circ} \mathrm{C}$ and thereafter it decreases. Other brazing alloys elements, $\mathrm{Cu}$ and $\mathrm{Ag}$, also decrease similarly to $\mathrm{Ti}$. At $950^{\circ} \mathrm{C}$ Ti and $\mathrm{Cu}$ are mainly substituted by $\mathrm{Fe}$ (around 33 at\%), $\mathrm{Cr}$ and $\mathrm{Ni}$. The reaction layer thickness presents the same evolution of the Ti amounts (see
Fig. 3). In the system $316 / \mathrm{Al}_{2} \mathrm{O}_{3}$, when using the brazing alloy CB5 with only $1.5 \%$ Ti the reaction layer thickness and its chemical composition follows the same evolution, as it is possible to observe in Fig. 4. With the increase of brazing temperature the reaction layer thickness and its Ti amount decreases. This reduction of the $\mathrm{Ti}$ amount on the reaction layer is balanced by the increase of other brazing elements $(\mathrm{Cu}$ and $\mathrm{Ag}), \mathrm{Fe}, \mathrm{Cr}$ and $\mathrm{Ni}$.

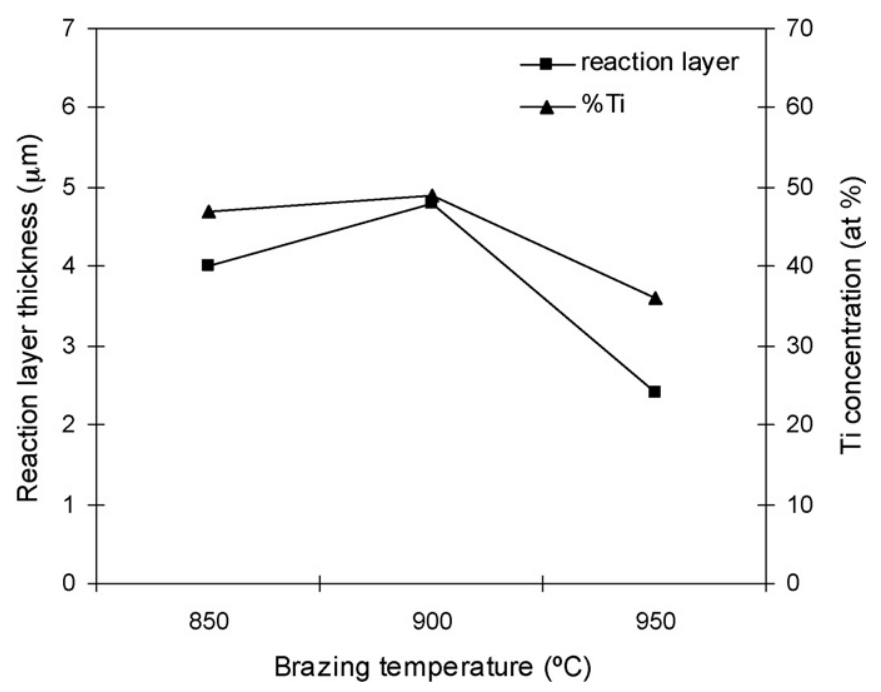

Fig. 3. $316 / \mathrm{Ag}-26.5 \mathrm{Cu}-3 \mathrm{Ti}(\mathrm{CB} 4) / \mathrm{Al}_{2} \mathrm{O}_{3}$ joints reaction layer thickness $(\mu \mathrm{m})$ and $\mathrm{Ti}$ concentration (at $\%)$. 


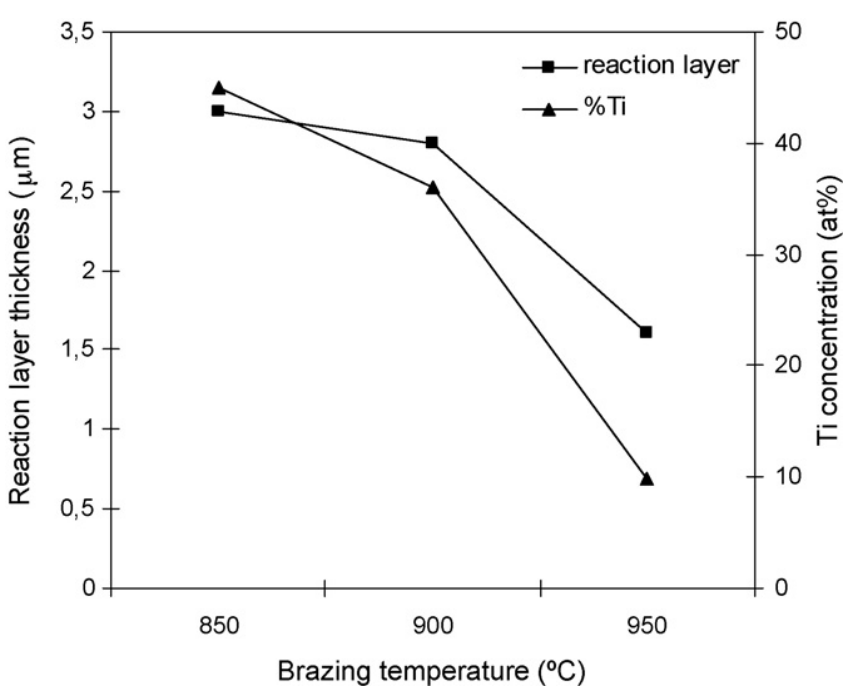

Fig. 4. $316 / \mathrm{Ag}-34.5 \mathrm{Cu}-1.5 \mathrm{Ti}(\mathrm{CB} 5) / \mathrm{Al}_{2} \mathrm{O}_{3}$ joints reaction layer thickness $(\mu \mathrm{m})$ and Ti concentration (at\%).

The amounts of Ti, $\mathrm{Ni}$ and $\mathrm{Cr}$ detected on $316 / \mathrm{CB} 5 / \mathrm{Al}_{2} \mathrm{O}_{3}$ joints reaction layers were lower than the amounts on $316 / \mathrm{CB} 4 / \mathrm{Al}_{2} \mathrm{O}_{3}$ joints.

The reaction layer chemical composition and thickness variations may be explained in terms of diffusion kinetics of elements in particularly the $\mathrm{Ti}, \mathrm{Fe} \mathrm{Cr}$ and $\mathrm{Ni}$. At lower brazing temperatures, $850{ }^{\circ} \mathrm{C}$, in the first step the Ti of brazing alloys is attracted preferentially by the alumina surface due to its great affinity to oxygen but also to the stainless steel surface due to the presence of Fe. When one increases the brazing temperature the mobility of $\mathrm{Ti}$ is enhanced and its diffusion occurs preferentially to 316/brazing alloy interface. This movement of Ti from brazing alloy to 316 surfaces is balanced by the diffusion of $\mathrm{Fe}$ and some $\mathrm{Ni}$ and $\mathrm{Cr}$ to brazing alloy/ $/ \mathrm{Al}_{2} \mathrm{O}_{3}$ interface. The differences between $316 / \mathrm{CB} 4 / \mathrm{Al}_{2} \mathrm{O}_{3}$ and $316 / \mathrm{CB} / / \mathrm{Al}_{2} \mathrm{O}_{3}$ joints diffusion kinetics can be explained in terms of chemical composition of the brazing alloys $\mathrm{CB} 4(\mathrm{Ag}-26.5 \mathrm{Cu}-3 \mathrm{Ti})$ and $\mathrm{CB} 5$ $(\mathrm{Ag}-34.5 \mathrm{Cu}-1.5 \mathrm{Ti})$, and its solidus and liquidus temperatures.

\subsection{Mechanical properties}

Fig. 5 presents the $316 / \mathrm{CB} 4 / \mathrm{Al}_{2} \mathrm{O}_{3}$ and $316 / \mathrm{CB} 5 / \mathrm{Al}_{2} \mathrm{O}_{3}$ joints shear strength results. The joints $316 / \mathrm{CB} 4 / \mathrm{Al}_{2} \mathrm{O}_{3}$ produced at $850{ }^{\circ} \mathrm{C}$ presents the best shear strength results, $234 \pm 18 \mathrm{MPa}$. The best results for the system $316 / \mathrm{CB} 5 / \mathrm{Al}_{2} \mathrm{O}_{3}$ were obtained with the joints produced at $900^{\circ} \mathrm{C}, 224 \pm 24 \mathrm{MPa}$. The shear strength evolution/measurement is different for the two systems as it possible to observe in Fig. 5. For the joints produced with CB4, using brazing temperatures ranging between 850 and $950^{\circ} \mathrm{C}$, the shear strength results decrease with the increase of brazing temperature; while with $\mathrm{CB} 5$ the best results were attained to $900^{\circ} \mathrm{C}$. The best results attained with $\mathrm{CB} 4$ (3 at\% Ti) and CB5 (1.5 at\% Ti) are very similar, although the differences of CB4 and CB5 in terms of chemical composition, specially the reactive element, and consequent wettability behaviour. The brazing alloy CB4 present lower contact angles than CB5 [17], this means that CB4 brazing alloy presents a

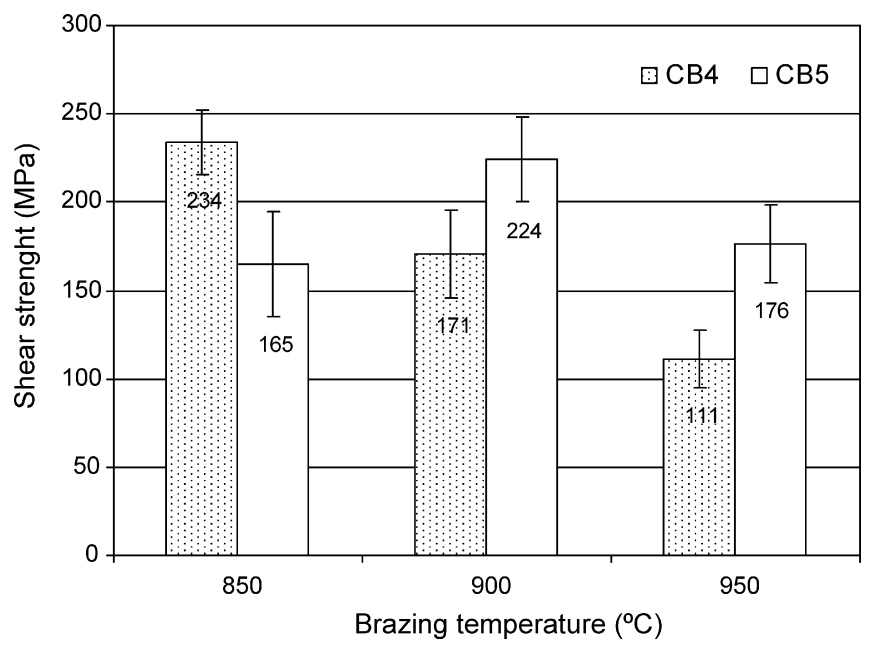

Fig. 5. Shear strength results of $316 / \mathrm{CB} 4 / \mathrm{Al}_{2} \mathrm{O}_{3}$ and $316 / \mathrm{CB} 5 / \mathrm{Al}_{2} \mathrm{O}_{3}$ joints produced at several brazing temperatures and a holding time of $20 \mathrm{~min}$.

superior wettability than CB5 due to the high amount of Ti on CB4 brazing alloy composition. The wettability increases, in both cases, with the increase of brazing temperature. The best shear strength results were attained for $316 / \mathrm{CB} 4 / \mathrm{Al}_{2} \mathrm{O}_{3}$ joints produced at $850^{\circ} \mathrm{C}$. Moreover, it is evident in different works [18-20] that the highest wettability rate does not assures the best mechanical behaviour. Analysing the CB5 shear strength results at 900 and $950^{\circ} \mathrm{C}$ one can easily see that those values are higher than the results obtained with CB4. For both brazing temperatures the reactions layers thickness and $\mathrm{Ti}$ amount are lower for the joints produced with CB4. This means that a great extension of reaction layer does not mean for sure a higher $\mathrm{M} / \mathrm{C}$ joint mechanical performance $[4,21,22]$. Meier et al. [21] conclude that in general for any metal/ceramic joint system it is fundamental to control the reaction layer thickness. This is due to the fact that the thicker the reaction layer the higher is the probability of weak reaction products formation leading to the consequent mechanical properties degradation.

Also Weise et al. [23] have shown that in the production of austenitic stainless steel (class not defined) $/ \mathrm{Al}_{2} \mathrm{O}_{3}$ joints, although the alumina wettability could be increased when using brazing alloys with elevated Ti concentrations ( $>3 \%$ weight), the mechanical behaviour of the joints undergoes a clear degradation under such conditions. Consequently, they suggested not to apply brazing alloys from the systems $\mathrm{Ag}-\mathrm{Cu}-\mathrm{Ti}$ and $\mathrm{Ag}-\mathrm{Cu}-\mathrm{Sn}-\mathrm{Ti}$ with Ti concentrations higher than 3-4\%.

The fracture surfaces of the joints were analysed by SEM/EDS and XRD in order to determine the fracture mode and to localize the joint fracture propagation. In Fig. $6 \mathrm{a}$ it is presented a fracture surface correspondent to a $316 / \mathrm{CB} 4 / \mathrm{Al}_{2} \mathrm{O}_{3}$ joint produced at $850^{\circ} \mathrm{C}$ (alumina side), and a magnification (Fig. 6b) of the fracture trajectory (SEM image obtained in backscattered electrons mode) and the respective EDS semi-quantification. As it is possible to observe in Fig. 6 the fractures initiated on $\mathrm{Al}_{2} \mathrm{O}_{3}$ and its propagation occurs essentially trough it, with certain contact zones with $\mathrm{CB} 4 / \mathrm{Al}_{2} \mathrm{O}_{3}$ interface (reaction layer), very near of the alumina surface, only visible in backscattering image mode. The EDS analysis of this zone indicated that 

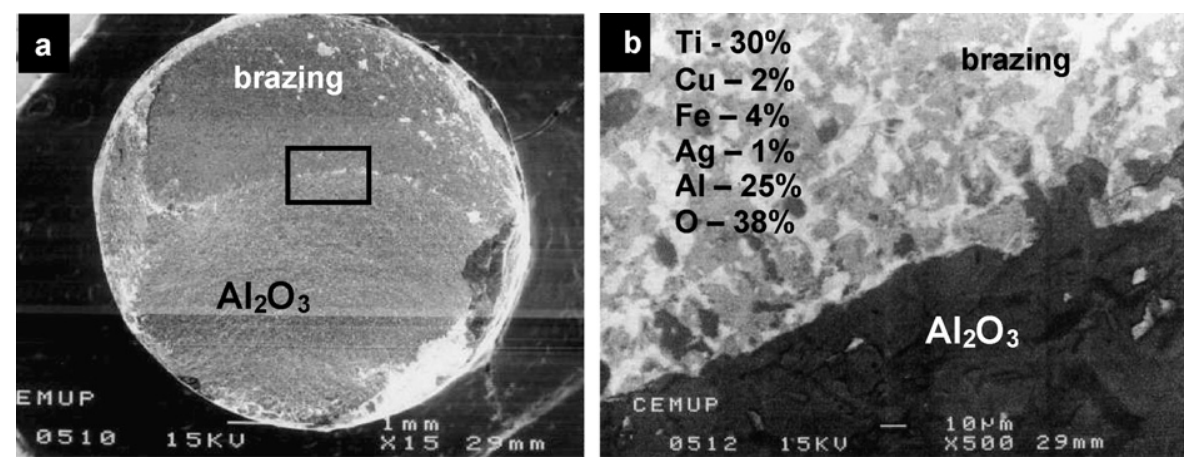

Fig. 6. Fracture surface of $316 / \mathrm{CB} 4 / \mathrm{Al}_{2} \mathrm{O}_{3}$ joints produced at $850^{\circ} \mathrm{C}\left(\mathrm{Al}_{2} \mathrm{O}_{3}\right.$ side): (a) general view of fracture, (b) magnification of image (a) and EDS analysis (at\%).

the fracture proximity of alumina surface. This fracture mode is attributed to elevated integrity $\mathrm{M} / \mathrm{C}$ joints $[24,25]$; this means that, the brittle part of joint is the ceramic and not the joining.

Fig. 7 shows fracture surfaces (alumina side) X-ray diffraction spectra of alumina and $316 / \mathrm{CB} 4 / \mathrm{Al}_{2} \mathrm{O}_{3}$ joints produced at 850 and $900^{\circ} \mathrm{C}$. We have compared the fracture surfaces spectra with the original alumina spectrum. It was found that only in the range of $35^{\circ}<2 \theta<43^{\circ}$ (although the $2 \theta$ angles were scanned from $15^{\circ}$ to $90^{\circ}$ ) one could detect measurable peaks correspondent to the reaction products formation on the fracture surface. This observation confirms the fact that the fracture occurs preferentially through the alumina with smalls incursions on the

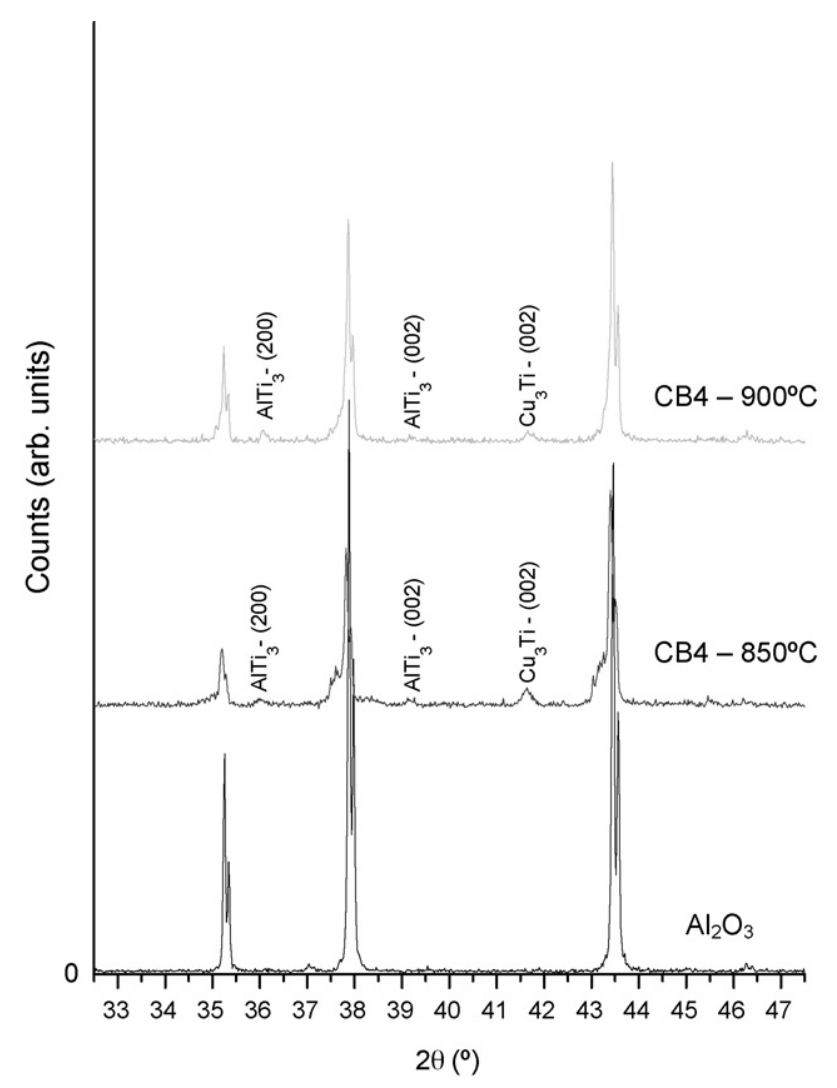

Fig. 7. Fracture surface $\mathrm{X}$-ray spectra (XRD) of $316 / \mathrm{CB} 4 / \mathrm{Al}_{2} \mathrm{O}_{3}$ joints produced at 850 and $900{ }^{\circ} \mathrm{C}$ as compared to the XRD spectra of the original alumina.
$\mathrm{Al}_{2} \mathrm{O}_{3} /$ brazing alloy interfaces. In the fracture surfaces all peaks corresponding to alumina reflections appears with low intensity and with high width at half height, this means that a loss of crystalline occurred during the brazing process.

In Fig. 7 the peaks identified, using the ASTM Powder Diffraction Standards [26] as $\mathrm{AlTi}_{3}\left(2 \theta=36.1^{\circ}\right.$ and $\left.39.1^{\circ}\right)$ correspond, respectively, to reflections of $20 \%$ and $25 \%$ of intensity, the peaks most important after the $100 \%$ peak intensity localized to $2 \theta=41.167^{\circ}$. The peak $2 \theta=41.6^{\circ}$ was identified as corresponding to $\mathrm{Cu}_{3} \mathrm{Ti}$ (50\% intensity) but with some restrictions. Some authors report the presence of $\mathrm{TiO}$ and $\mathrm{TiO}_{2}$, in very small amounts, and $\mathrm{CuTi}_{2}$, in interfaces stainless steel (1Cr18Ni9Ti)/Ag-Cu-Ti/ $/ \mathrm{Al}_{2} \mathrm{O}_{3}$ [4,5]. Studies carried out by Lee et al. [27] in stainless steel $304 / \mathrm{Ag}-\mathrm{Cu}-\mathrm{Ti} / \mathrm{Al}_{2} \mathrm{O}_{3}$ joints have identified the presence of $\mathrm{TiO}, \mathrm{Fe}_{2} \mathrm{Ti}_{4} \mathrm{O}$ and $\mathrm{Cu}_{2} \mathrm{Ti}_{4} \mathrm{O}$ on the reaction layer. They have also reported the presence of $\mathrm{Fe}_{2} \mathrm{Ti}_{4} \mathrm{O}$ and $\mathrm{Cu}_{2} \mathrm{Ti}_{4} \mathrm{O}$ compounds, that can be possibly considered to be in the form $(\mathrm{Cu}, \mathrm{Fe})_{2} \mathrm{Ti}_{4} \mathrm{O}$ [27]. Taking into account that information, the $\mathrm{AlTi}_{3}$ peaks can be eventually attributed to the following $\mathrm{TiO}_{2}$ reflections: $2 \theta=36.252^{\circ}(012)$, with $25 \%$ of intensity and $2 \theta=39.205^{\circ}(040)$, with $5 \%$ of intensity [26]. Also the peak attributed to the $\mathrm{Cu}_{3} \mathrm{Ti}$ compound, with $2 \theta=41.6^{\circ}$, may be eventually attributed to the $\mathrm{Cu}_{2} \mathrm{Ti}_{4} \mathrm{O}$ compound, with two reflections very next of $2 \theta=41.6^{\circ}: 2 \theta=41.108^{\circ}(511), 100 \%$ intensity and $2 \theta=42.092^{\circ}(520), 5 \%$ intensity [26].

The $\mathrm{AlTi}_{3}$ formation is in according to Loehman and Tomsia [3] thermodynamic calculations for to $\mathrm{Ag}-\mathrm{Cu}-\mathrm{Ti} / \mathrm{Al}_{2} \mathrm{O}_{3}$ systerms These investigators have shown that independently of the used metal in the metal- $\mathrm{Al}_{2} \mathrm{O}_{3}$, the $\mathrm{AlTi}_{3}$ formation occurs according to the following reaction [3]: $8 \mathrm{Ti}+\mathrm{Al}_{2} \mathrm{O}_{3} \leftrightarrow 3 \mathrm{TiO}_{0.5}+2 \mathrm{AlTi}_{3}$.

Relatively to the fracture surfaces of the $316 / \mathrm{CB} 5 / \mathrm{Al}_{2} \mathrm{O}_{3}$ joints, it was observed that the fracture initiation occurs always in the ceramic, and its propagation occurs mainly throughout the ceramic as it was discussed for the joints produced with CB4. On the joints produced at $900^{\circ} \mathrm{C}$, exhibiting the best shear strength performance, the fracture initiation ant its propagation occurs totally throughout the ceramic. In the X-ray studies, carried out at the fracture surfaces, of the $\mathrm{M} / \mathrm{C}$ joints produced at $850^{\circ} \mathrm{C}$, it was not possible to identify the formation of reaction products. The X-ray spectra obtained were very similar to $\mathrm{Al}_{2} \mathrm{O}_{3}$ spectrum only it was observed a reduction of $\mathrm{Al}_{2} \mathrm{O}_{3}$ characteristics peaks 


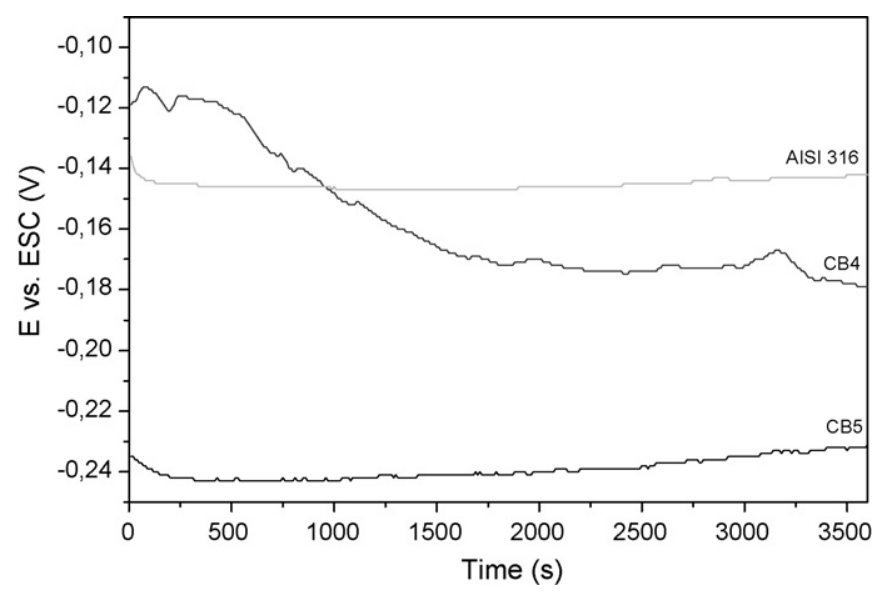

Fig. 8. Open-circuit potential curves for AISI 316 stainless steel and brazing alloys CB4 and CB5.

intensity. This means that as it was reported for the $\mathrm{CB} 4$ system it occur the amorphization of $\mathrm{Al}_{2} \mathrm{O}_{3}$ near the joining interface.

\subsection{Degradation}

Figs. 8 and 9 present one example of the obtained opencircuit potential $\left(E_{\text {corr }}\right)$ curves, and the corrosion current density $\left(i_{\text {corr }}\right)$ curves, for both brazing alloys $\mathrm{CB} 4(\mathrm{Ag}-26.5 \mathrm{Cu}-3 \mathrm{Ti})$, CB5 (Ag-34.5Cu-1.5Ti) and AISI 316 stainless steel. The opencircuit potential evolution of brazing alloys, as well as the 316 is very similar for all experiments carried out. For the 316 it is visible that the open-circuit potential after $60 \mathrm{~min}$ of immersion in HBSS at $37 \pm 2{ }^{\circ} \mathrm{C}$ is stabilized and its value is around $-96 \pm 27 \mathrm{mV}$. Relatively to brazing alloys, the CB4 alloy presents a more noble potential than the CB5 alloy. However, when analysing the open-circuit potential curves, in both cases it appears that it is not attained an equilibrium state, and the evolution of the curves presented in Fig. 8 show a tendency to the increase of CB5 potential and the continuous decrease of the CB4 potential. However, at the end of the experiments the difference between the CB4 and CB5 potentials appears rather insignificant, $-201 \pm 21$ and $-221 \pm 11 \mathrm{mV}$, respectively. As

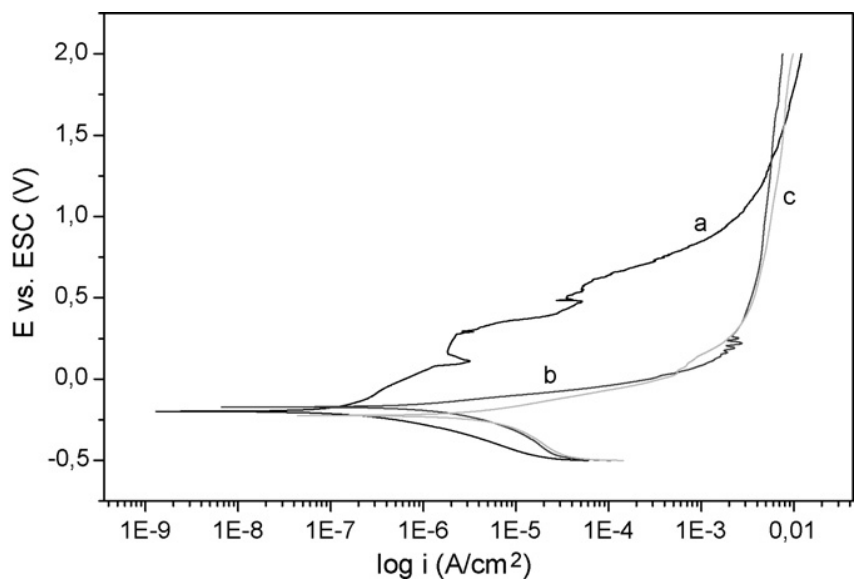

Fig. 9. Polarization curves: (a) AISI 316 stainless steel, (b) CB4 brazing alloy and (c) CB5 brazing alloy. it was expected the stainless steel presented a behaviour more noble than the brazing alloys. This means that in chloride environments (low $\mathrm{Cl}^{-}$concentration) the austenitic stainless steels present a lower thermodynamic tendency to degradation than the copper-silver alloys [28]. In fact, in medical applications, around $90 \%$ of the fracture fixation systems are produced in stainless steel mainly in the AISI 316 group [29]. This explains its behaviour (the low tendency to corrode) in HBSS.

Fig. 9 presents the polarization curves of the three metallic base materials. The evaluation of polarization curves of $\mathrm{CB} 4$ and CB5 is quite similar, although the CB5 corrosion velocity $\left(i_{\text {corr }}\right)$ was found to be double of the CB4 corrosion velocity, $8.96 \pm 1.15$ and $4.82 \pm 1.32 \mu \mathrm{A} \mathrm{cm}^{-2}$, respectively. The great differences between the 316 and the brazing alloys polarization curves occur in the cathodic polarization and in the beginning of the anodic polarization curves. This difference is related with the fact that the degradation film formed on 316 surfaces during the immersion of $60 \mathrm{~min}$ in HBSS is much more resistant and stable than the brazing alloys degradation films and consequently much more difficult to destroy during the polarization, presenting a corrosion current density of $0.56 \pm 0.21 \mu \mathrm{A} \mathrm{cm}^{-2}$.

Fig. 10 presents the open-circuit potential results, after 60 min of immersion, in HBSS for both $316 / \mathrm{CB} 4 / \mathrm{Al}_{2} \mathrm{O}_{3}$ and $316 / \mathrm{CB} 5 / \mathrm{Al}_{2} \mathrm{O}_{3}$ joints. The first observation is related with the fact of the $316 / \mathrm{Al}_{2} \mathrm{O}_{3}$ joints produced with both brazing alloys being found to present a tendency to corrosion lower than the respective brazing alloy, but always an active behaviour when compared with the 316 stainless steel. Although the brazing alloy CB5 was found to present a more active behaviour than CB4 creating the expectation of the same behaviour for the respective joints, the $316 / \mathrm{CB} 5 / \mathrm{Al}_{2} \mathrm{O}_{3}$ joints produced at $950^{\circ} \mathrm{C}$ were observed to be more stable than the joints produced with $\mathrm{CB} 4$ for the same brazing temperature. The brazing thermal cycle changed the brazing alloy microstructure and originated a different distribution of the rich-Cu areas, more active in chloride environments, and rich-Ag areas (more noble) inside the joint $[16,30]$. Nevertheless, the open-circuit potentials measured in $\mathrm{M} / \mathrm{C}$ joints are quite similar. This means that all $\mathrm{M} / \mathrm{C}$ joints present similar thermodynamic tendency to suffer degradation.

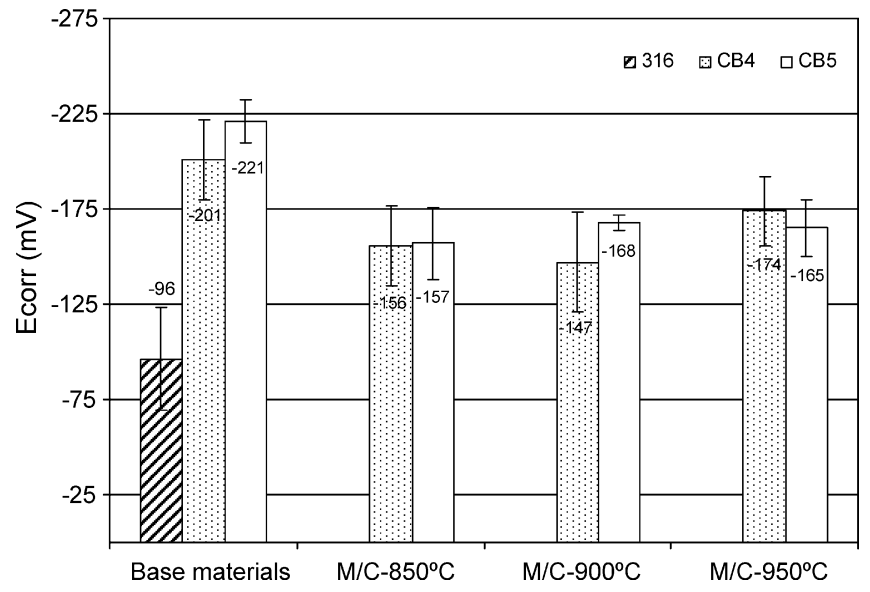

Fig. 10. Open-circuit potentials ( $E_{\text {corr }}$ ) for $316 / \mathrm{CB} 4 / \mathrm{Al}_{2} \mathrm{O}_{3}, 316 / \mathrm{CB} 5 / \mathrm{Al}_{2} \mathrm{O}_{3}$, brazing alloys and AISI 316 stainless steel. 


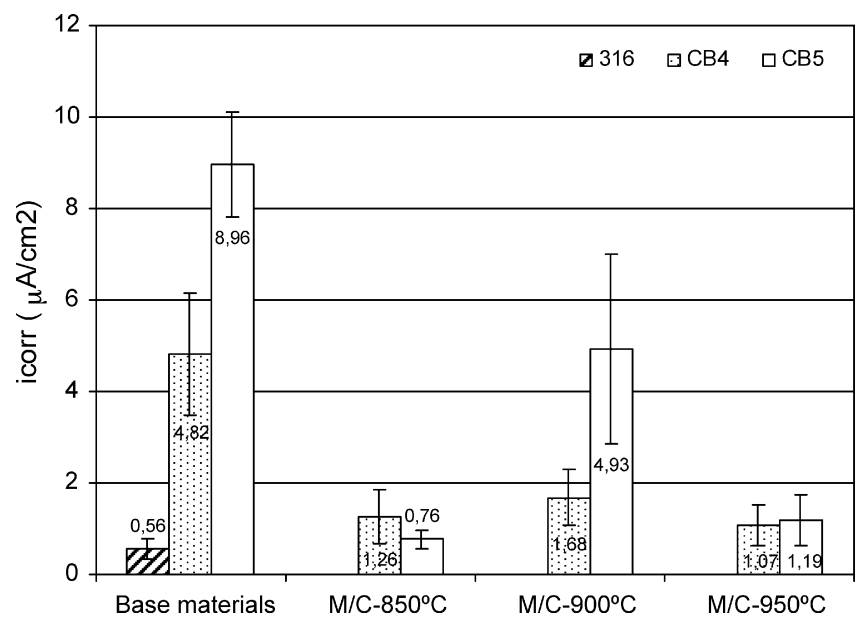

Fig. 11. Current corrosion density $\left(i_{\text {corr }}\right)$ for $316 / C B 4 / \mathrm{Al}_{2} \mathrm{O}_{3}$ and $316 / \mathrm{CB} 5 / \mathrm{Al}_{2} \mathrm{O}_{3}$ joints, brazing alloys $\mathrm{CB} 4$ and $\mathrm{CB} 5$, and AISI 316 stainless steel.

This similarity clearly eliminates the possibility to use the opencircuit potential as a selection criterion of brazing parameters or a selection criterion of brazing alloy chemical composition for the production of the $\mathrm{M} / \mathrm{C}$ joints with the best corrosion behaviour.

The best behaviour presented by the $316 / \mathrm{Al}_{2} \mathrm{O}_{3}$ joints relatively to the brazing alloys used on its production, is a new situation in comparison with the system $\mathrm{Ti} / \mathrm{Al}_{2} \mathrm{O}_{3}[7,9]$. In fact, when using the $\mathrm{CB} 4$ and $\mathrm{CB} 5$ alloys to produce $\mathrm{Ti} / \mathrm{Al}_{2} \mathrm{O}_{3}$ joints the joints always presented a more active character than the respective brazing alloys. This difference of behaviours can be related with the fact that commercially pure titanium and stainless steel AISI 316 exhibit very distinct corrosion tendencies in chloride environments [31]. In comparison with Ti the differences between the open-circuit potentials of AISI 316 and the brazing alloys are less significant than the differences found between $\mathrm{Ti}$ and the same brazing alloys. Consequently, the possibility of occurrence of galvanic corrosion phenomena in the $316 / \mathrm{Al}_{2} \mathrm{O}_{3}$ systems, is significantly inferior as compared to $\mathrm{Ti} / \mathrm{Al}_{2} \mathrm{O}_{3}[31,32]$, even knowing that the anodic reaction continues to occur in the brazing and the relationship between cathodic areas (the stainless steel) and anodic areas (the brazing) is clearly to be disfavorable to the brazing. Those observations are in accordance to works carried out by Paiva et al. [32,33], testing $\mathrm{Ti} / \mathrm{Al}_{2} \mathrm{O}_{3}$ and $316 / \mathrm{Al}_{2} \mathrm{O}_{3}$ joints in HBSS a $37 \pm 2{ }^{\circ} \mathrm{C}$. On those works it was possible to determine that the $\mathrm{Ti} / \mathrm{Al}_{2} \mathrm{O}_{3}$ joints present a more active character being the reason for that attributed to galvanic corrosion phenomena.

When analysing the $\mathrm{M} / \mathrm{C}$ joints behaviour in terms of degradation kinetics one can notice some differences between the brazing alloys and the $316 / \mathrm{Al}_{2} \mathrm{O}_{3}$ joints behaviour, clearly as it observed in Fig. 11. The CB5 brazing alloy with the high amount of $\mathrm{Cu}(34.5 \%)$ and the lower amount of $\mathrm{Ti}(1.5 \%)$, presents a corrosion velocity that is roughly twice the $\mathrm{CB} 4$ corrosion velocity. However, not all $\mathrm{M} / \mathrm{C}$ joints produced with each brazing alloy present that tendency. For instances, the $316 / \mathrm{CB} 5 / \mathrm{Al}_{2} \mathrm{O}_{3}$ joints produced at $850^{\circ} \mathrm{C}$ present a corrosion velocity around half $\left(0.76 \pm 0.21 \mu \mathrm{A} \mathrm{cm}^{-2}\right)$ of the $316 / \mathrm{CB} 4 / \mathrm{Al}_{2} \mathrm{O}_{3}$ joints cor-

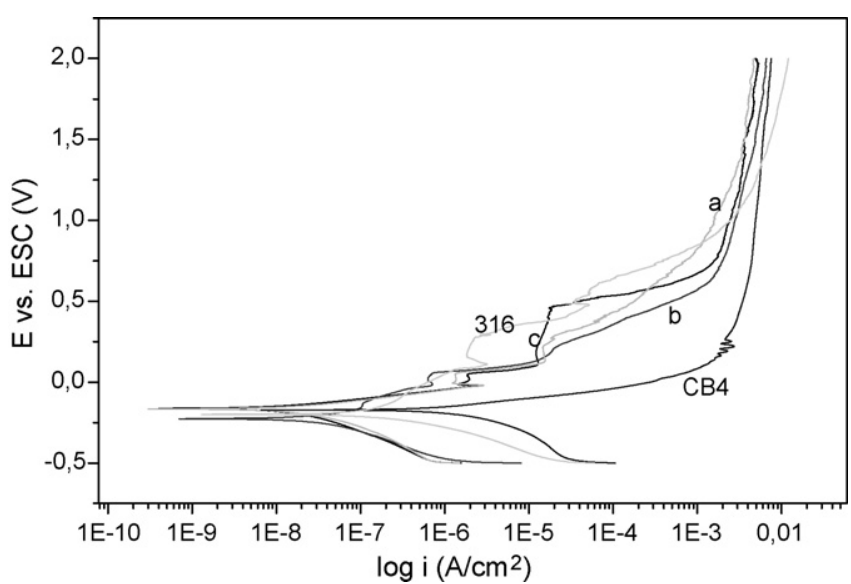

Fig. 12. Potentiodynamic polarization curves: (a) $316 / \mathrm{CB} 4 / \mathrm{Al}_{2} \mathrm{O}_{3}, 850^{\circ} \mathrm{C}$; (b) $316 / \mathrm{CB} 4 / \mathrm{Al}_{2} \mathrm{O}_{3}, 900{ }^{\circ} \mathrm{C}$; (c) $316 / \mathrm{CB} 4 / \mathrm{Al}_{2} \mathrm{O}_{3}, 950^{\circ} \mathrm{C}$; AISI 316 stainless steel and CB4 brazing alloy.

rosion velocity. These differences can to be attributed to the joint microstructure especially to the anodic areas (rich in $\mathrm{Cu}$ ) and the cathodic (rich in $\mathrm{Ag}$ ), whose behaviour was previously discussed. One can also emphasize negatively the behaviour of the $316 / \mathrm{CB} 5 / \mathrm{Al}_{2} \mathrm{O}_{3}$ joints produced at $900{ }^{\circ} \mathrm{C}$, which presented corrosion current densities of $4.93 \pm 2.06 \mu \mathrm{A} \mathrm{cm}^{-2}$, a high value when compared with the others joints.

In Figs. 12 and 13 are presented typical potentiodynamic polarization curves for $316 / \mathrm{CB} 4 / \mathrm{Al}_{2} \mathrm{O}_{3}$ and $316 / \mathrm{CB} 5 / \mathrm{Al}_{2} \mathrm{O}_{3}$ joints. In both figures it is noticeable, the most active behaviour of brazing alloys in comparison with the respective $\mathrm{M} / \mathrm{C}$ joints, the curves "noses" for brazing alloys occurs at higher corrosion current densities. Is also perceptible that all $\mathrm{M} / \mathrm{C}$ joints polarization curves are located between the 316 curve (the material with the noblest behaviour), and the brazing alloys curves.

When comparing the open-circuit potential and polarization experiments, it results that the corrosion velocity is the most trustable measure to select the brazing parameters and chemical composition of brazing alloy, when the selection is based in electrochemical tests. The effect of Ti amount present on

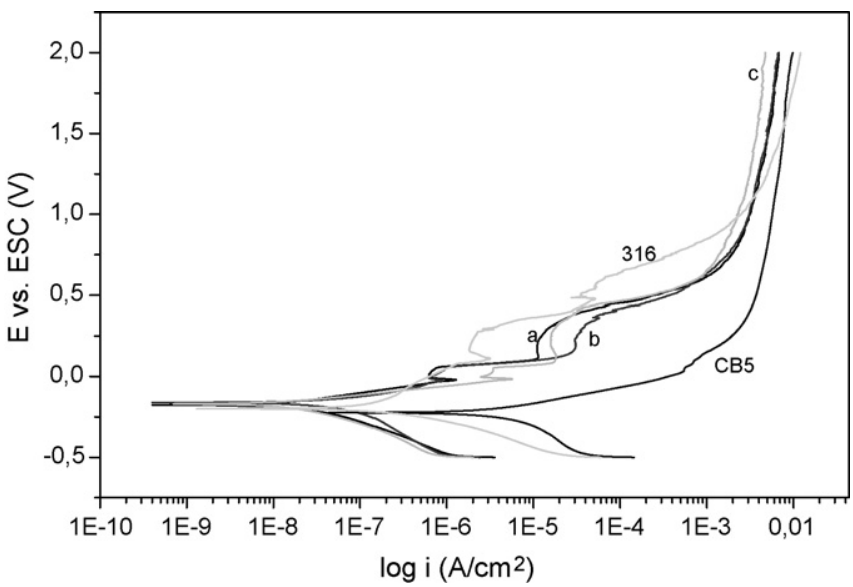

Fig. 13. Potentiodynamic polarization curves: (a) $316 / \mathrm{CB} 5 / \mathrm{Al}_{2} \mathrm{O}_{3}, 850^{\circ} \mathrm{C}$; (b) $316 / \mathrm{CB} 5 / \mathrm{Al}_{2} \mathrm{O}_{3}, 900{ }^{\circ} \mathrm{C}$; (c) $316 / \mathrm{CB} 5 / \mathrm{Al}_{2} \mathrm{O}_{3}, 950{ }^{\circ} \mathrm{C}$; AISI 316 stainless steel and brazing alloy CB5. 

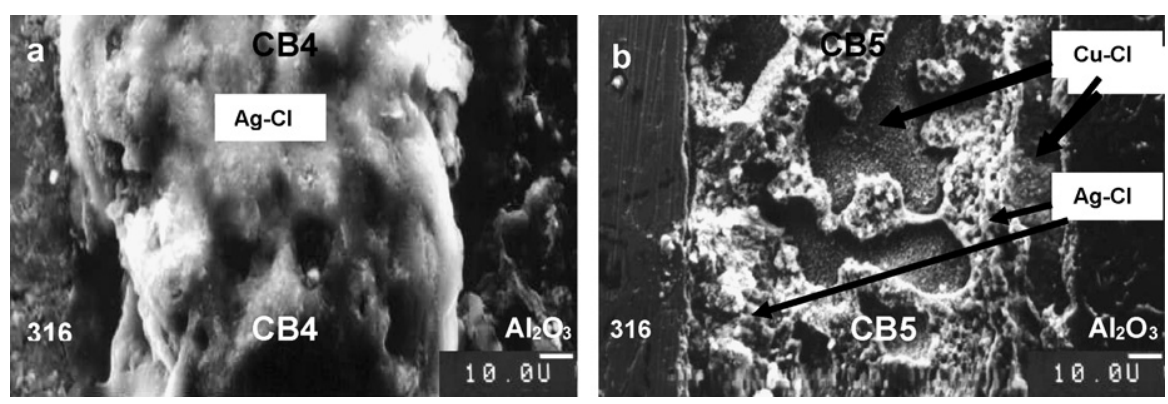

Fig. 14. General view of $316 / \mathrm{CB} 4 / \mathrm{Al}_{2} \mathrm{O}_{3}$ interfaces (a) and $316 / \mathrm{CB} 5 / \mathrm{Al}_{2} \mathrm{O}_{3}$ joints (b) produced at $900{ }^{\circ} \mathrm{C}$ after the electrochemical tests carried out in $\mathrm{HBSS}$ at $37 \pm 2{ }^{\circ} \mathrm{C}$.

the brazing alloys in the $\mathrm{M} / \mathrm{C}$ joints is difficult to evaluate because the corrosion velocities appears more related and dependent of the distribution of $\mathrm{Cu}$ and $\mathrm{Ag}$ in the interface microstructure.

After the electrochemical experiments, the degradation products formed in the $\mathrm{M} / \mathrm{C}$ interfaces were observed and analysed by SEM/EDS. Fig. 14 presents photomicrographies of $316 / \mathrm{CB} 4 / \mathrm{Al}_{2} \mathrm{O}_{3}$ and $316 / \mathrm{CB} 5 / \mathrm{Al}_{2} \mathrm{O}_{3}$ interfaces both produced at $900{ }^{\circ} \mathrm{C}$. This brazing temperature had originated the worst results in terms of corrosion velocity, in particularly with CB5 brazing alloy with a corrosion velocity of $4.93 \pm 2.06 \mu \mathrm{A} \mathrm{cm}^{-2}$. The 316/CB5/ $/ \mathrm{Al}_{2} \mathrm{O}_{3}$ interface (Fig. 14b) suffers active corrosion and the degradation products were release to the corrosion media. It is also possible to confirm that the areas rich in $\mathrm{Cu}$, the globular areas and a layer near the $\mathrm{Al}_{2} \mathrm{O}_{3}$ surface, were the areas preferentially attached. Otherwise, observing the (Fig. 14a) the interface the degradation products originated the formation of a dense film, compact characterized by a great adhesion to the brazing it self. The other interfaces the degradation products were presented this type of morphology.

The chemical composition of these degradation products is presented in Table 2. The analysis of these products should be making integrated with the interfaces microstructures after the corrosion tests. The results presented in Table 2 do not show significant differences between the interfaces produced with each brazing parameters. In an isolated analysis, the differences of the degradation products composition formed in $316 / \mathrm{CB} 4 / \mathrm{Al}_{2} \mathrm{O}_{3}$ and $316 / \mathrm{CB} 5 / \mathrm{Al}_{2} \mathrm{O}_{3}$ interfaces, both produced at $900^{\circ} \mathrm{C}$, did not enough to justify the differences in terms of corrosion velocities. However, by means of analysing the $316 / \mathrm{CB} 4 / \mathrm{Al}_{2} \mathrm{O}_{3}$ interface (see Fig. 14a), it is possible to observe the formation of a very dense film of $\mathrm{AgCl}$ forming a barrier to degradation environment. While, in the $316 / \mathrm{CB} 5 / \mathrm{Al}_{2} \mathrm{O}_{3}$ interfaces, the $\mathrm{Cu}$ analysed corresponding to $\mathrm{Cl}$ ions attached areas, and the products resulting of this attached released to the solution. The remainder areas are basically composed by $\mathrm{Ag}$ and $\mathrm{Cl}$, probably under $\mathrm{AgCl}$ forms, most stable than $\mathrm{CuCl}$ (white areas of Fig. 14b). This analysis is based on the fact that $\mathrm{AgCl}$ and $\mathrm{CuCl}$ are the degradation products with great probably to be formed at the $\mathrm{M} / \mathrm{C}$ interfaces and the stability of each compound [interfaces $\mathrm{Ti} / \mathrm{Al}_{2} \mathrm{O}_{3}$ references]. The tendency of $\mathrm{CuCl}$ to be released to the solution is higher than $\mathrm{AgCl}$ do to its solubility products (Kps), $1.2 \times 10^{-6}$ and $0.7 \times 10^{-12}$, respectively [34]. This means that when preferentially occur the formation of $\mathrm{AgCl}$ the degradation presenting a protection $\mathrm{M} / \mathrm{C}$ joint character forming a barrier-like film, when the formation of $\mathrm{CuCl}$ is sign cant, this is dissolved by the degradation solution and do not contribute to the $\mathrm{M} / \mathrm{C}$ interface protection. These results are in accordance to Janssens et al. [35] observations during the implantation, of Ti/ceramic glass interfaces produced with Ag-based brazing alloys, in pigs. They observed the films formation rich on $\mathrm{Ag}$ at the interface but did not observe inflammatory reactions in the animals [35].

This observation making credible that the $\mathrm{M} / \mathrm{C}$ interfaces produced in this work, namely the $\mathrm{M} / \mathrm{C}$ interfaces presenting the formation of based $\mathrm{Ag}-\mathrm{Cl}$ degradation film, can be considered with great potential to be used in biomedical applications. Moreover, it is well known that the materials containing Ag in high concentrations, present antibacterians properties [36]. This characteristic can be of great importance during the implantation period.

Table 2

Chemical composition as determined by EDS of the degradation products formed in the $316 / \mathrm{Al}_{2} \mathrm{O}_{3}$ joints during the electrochemical tests

\begin{tabular}{|c|c|c|c|c|c|c|c|c|}
\hline $\mathrm{M} / \mathrm{C}$ system & Brazing temperature $\left({ }^{\circ} \mathrm{C}\right)$ & \multicolumn{7}{|c|}{ Degradation products composition (at\%) } \\
\hline \multirow[t]{2}{*}{$316 / \mathrm{CB} 4 / \mathrm{Al}_{2} \mathrm{O}_{3}(\mathrm{Ag}-26.5 \mathrm{Cu}-3 \mathrm{Ti})$} & 850 & 17 & 29 & 2 & 7 & 3 & 25 & 17 \\
\hline & 950 & 53 & 3 & 1 & 2 & 3 & 35 & 3 \\
\hline \multirow[t]{2}{*}{$316 / \mathrm{CB} 5 / \mathrm{Al}_{2} \mathrm{O}_{3}(\mathrm{Ag}-34.5 \mathrm{Cu}-1.5 \mathrm{Ti})$} & 850 & 46 & 21 & 2 & 3 & 1 & 20 & 10 \\
\hline & $900^{\mathrm{a}}$ & 36 & 25 & 3 & 2 & 2 & 27 & 5 \\
\hline
\end{tabular}

\footnotetext{
${ }^{a}$ It is not observed the formation of continuous film, the joint surface is exposed.
} 


\section{Conclusions}

For all brazing temperatures it was possible to produce $316 / \mathrm{CB} 4 / \mathrm{Al}_{2} \mathrm{O}_{3}$ and $316 / \mathrm{CB} 5 / \mathrm{Al}_{2} \mathrm{O}_{3}$ joints free of porosities and cracks. Do to the high amount of $\mathrm{Ti}$ in the brazing alloy CB4 (Ag-26.5Cu-3Ti) the reaction layers of $316 / \mathrm{CB} 4 / \mathrm{Al}_{2} \mathrm{O}_{3}$ joints are thicker than in the $316 / \mathrm{CB} 5 / \mathrm{Al}_{2} \mathrm{O}_{3}$ joints. In the reaction layer, besides the high $\mathrm{Ti}$ amounts, $\mathrm{Fe}, \mathrm{Cr}$ and $\mathrm{Ni}$ were detected stemming from the 316 AISI stainless steel. It was observed that the $\mathrm{M} / \mathrm{C}$ joint microstructure is mainly dependent on brazing temperature.

The best mechanical behaviour, measured by means of submitting the AISI 316 stainless steel/ $\mathrm{Al}_{2} \mathrm{O}_{3}$ joints to shear strength tests was obtained using the following conditions:

- $\mathrm{CB} 4(\mathrm{Ag}-26.5 \mathrm{Cu}-3 \mathrm{Ti})-850^{\circ} \mathrm{C}-234 \pm 18 \mathrm{MPa}$,

- $\mathrm{CB} 5$ (Ag-34.5Cu-1.5Ti) - $900^{\circ} \mathrm{C}-224 \pm 24 \mathrm{MPa}$.

The best mechanical properties were not observed for the brazing parameters that give the best wetabilities. In fact, it was found that the joint morphology microstructure is the determining factor for its mechanical performance.

The electrochemical tests have shown that $316 / \mathrm{Al}_{2} \mathrm{O}_{3}$ joints could be used in aggressive environments, for instance chloride ions. There appears to exist a relationship between the corrosion current density $\left(i_{\text {corr }}\right)$ and the brazing temperature, as a result of the fact that each brazing temperature produces a distinct microstructure.

For the degradation behaviour of $316 / \mathrm{Al}_{2} \mathrm{O}_{3}$ joints the role of $\mathrm{Ti}$ amount present in the brazing alloys $\mathrm{CB} 4(\mathrm{Ag}-26.5 \mathrm{Cu}-3 \mathrm{Ti})$ and CB5 (Ag-34.5Cu-1.5Ti) appears to be secondary in comparison to the interface microstructure morphology, in particular the $\mathrm{Cu}$ and $\mathrm{Ag}$ distribution.

The best degradation results were obtained for 316/CB5/ $\mathrm{Al}_{2} \mathrm{O}_{3}$ joints produced at $850^{\circ} \mathrm{C}, 0.76 \pm 0.21 \mu \mathrm{A} \mathrm{cm}^{-2}$. The $316 / \mathrm{CB} 4 / \mathrm{Al}_{2} \mathrm{O}_{3}$ joints show a degradation behaviour less sensitive to the brazing temperature. However, the best result was obtained for joints produced at $950^{\circ} \mathrm{C}, 1.07 \pm 0.44 \mu \mathrm{A} \mathrm{cm}^{-2}$.

When $\mathrm{M} / \mathrm{C}$ joints need to be used in aggressive environments, electrochemical techniques are a good tool to be applied for the adequate brazing parameters selection. Based in the electrochemical experiments carried out in this work, it is recommend that one should use the corrosion current density $\left(i_{\text {corr }}\right)$ value as criterion for the selection of the brazing parameters as it appears to be the electrochemical parameter most sensitive to $\mathrm{M} / \mathrm{C}$ production conditions.

The $316 / \mathrm{CB} 4 / \mathrm{Al}_{2} \mathrm{O}_{3}$ joints produced at $850{ }^{\circ} \mathrm{C}$ exhibit the best compromise between electrochemical degradation and mechanical behaviour; a corrosion current density of $1.26 \pm 0.58 \mu \mathrm{A} \mathrm{cm}^{-2}$ and a shear strength of $234 \pm 18 \mathrm{MPa}$.

\section{References}

[1] M.M. Schwartz, in: M.M. Schwartz (Ed.), Ceramic Joining, ASM International, Ohio, 1990, pp. 75-140.
[2] M.G. Nicholas, Br. Ceram. Trans. J. 85 (1986) 144-146.

[3] R.E. Loehamn, A.P. Tomsia, Acta Metall. Mater. 40 (1992) S75-S83.

[4] H. Hao, Y. Wang, Z. Jin, X. Wang, J. Mater. Sci. 30 (1995) 41074111.

[5] H. Hao, Y. Wang, Z. Jin, X. Wang, J. Mater. Sci. 30 (1995) 12331239.

[6] L. Rongti, P. Wei, C. Jian, L. Jie, Mater. Sci. Eng. A 335 (2002) 2125.

[7] O.C. Paiva, M.A. Barbosa, J. Mater. Sci. 32 (1997) 653-659.

[8] O.C. Paiva, M.A. Barbosa, in: R. Kossowsky, N. Kossovsky (Eds.), Advances in Materials Science and Implant Orthopaedic Surgery, Kluwer Academic Publishers, Dordrecht, The Netherlands, 1995, pp. 275290.

[9] O.C. Paiva, M.A. Barbosa, J. Mater. Sci. 35 (2000) 1165-1175.

[10] L.A. Rocha, M.A. Barbosa, R. Puers, J. Mater Sci.: Mat. Med. 6 (1985) 835-838.

[11] O.C. Paiva, L. Ferreira, M.A. Barbosa, in: A. Bellosi, T. Kosmac e, A.P. Tomsia (Eds.), Interfacial Science in Ceramic Joining, NATO/ARW Series (3. High Technology), vol. 53, Kluwer Academic Press, Dordrecht, The Netherlands, 1998, pp. 329-340.

[12] E. Ariza, L.A. Rocha, O.C. Paiva, Eurocorr2004 Conference Proceedings, Nice, France, 2004, CD-Rom.

[13] H. Idrissi, S. Audisio, S. Elmouaffek, M. Chastrette, Materiaux et Techniques (1987) 433-437.

[14] H. Idrissi, J.P. Millet, S. Audisio, A. Irhzo, J. Mater. Sci. 29 (1994) 5327-5332.

[15] Y. Niu, F. Gesmundo, F. Viani, W. Wu, Oxidat. Met. 47 (1997) 21-52.

[16] M. Stern, A.L. Geary, Corrosion 13 (1957) 139-143.

[17] E. Saiz, R.M. Cannon, A.P. Tomsia, Acta Mater. 48 (2000) 4449-4462.

[18] S. Kang, Ceram. Bull. 68 (1989) 1608-1617.

[19] G. Elssner, G. Petzow, ISIJ Int. 30 (1990) 1011-1032.

[20] D.H. Kim, S.H. Wang, S.S. Chun, J. Mater. Sci. 26 (1991) 3223-3234.

[21] A. Meier, D.A. Javernick, G.R. Edwards, JOM (1999) 44-47.

[22] Y. Zhai, T.H. North, J. Ren, J. Mater. Sci. 32 (1997) 1399-1404.

[23] W. Weise, W. Malikowski, W. Bohm, Degussa AG, Hanau, Germany, Internal Report (1995).

[24] F. Moret, N. Eustathopoulos, Journal de Physique IV, Colloque C7 (3) (1993) 1043-1052.

[25] B. Gibbesch, G. Elssener, G. Petzow, Biomaterials 13 (7) (1992) 455461.

[26] Joint Committee on Powder Diffraction Standards, Powder Diffraction File, ASTM, Philadelphia, PA, 1992.

[27] W.C. Lee, O.Y. Kwon, C.S. Kang, J. Mater. Sci. 30 (1995) 1679_ 1688.

[28] L.L. Shreir, in: L.L. Shreir (Ed.), Corrosion-Metal/Environment Reactions, vol. 1, 2nd ed., Newnes-Butterworths, 1978, pp. 3:31-3:63.

[29] A.D. Bernache, in: M.A. Barbosa et al. (Ed.), Biomaterials Degradation. Fundamental aspects and related clinical phenomena, Elsevier, Amsterdam, E-MRS Monographs I, 1991, 111-167.

[30] C.A.C. Sequeira, Br. Corros. J. 30 (1995) 137-140.

[31] F.L. LaQue, in: F.L. LaQue (Ed.), Marine Corrosion, John Wiley \& Sons, 1975, p. 179.

[32] O.C. Paiva, M.A. Barbosa, in: R.Z. LeGeros, J. LeGeros (Eds.), Bioceramics 11, World Scientific Publishing Co. Pte. Ltd., Singapore, 1998, pp. 699-702.

[33] O.C. Paiva, M.A. Barbosa, in: H. Ohgushi, G.W. Hastings, T. Yoshikawa (Eds.), Bioceramics 12, World Scientific Publishing Co. Pte. Ltd., Singapore, 1999, pp. 95-98

[34] G.W. Walkiden, in: L.L. Shreir (Ed.), Corrosion-Metal/Environment Reactions, vol. 1, 2nd ed., Newnes-Butterworths, 1978, pp. 6:1-6:23.

[35] S. Janssens, L.A. Rocha, L. Bosschaerts, M.A. Barbosa, R. Puers, H. Villé, R. Geers, Prev. Vet. Med. 25 (1996) 249-258.

[36] D.L. Tsalev, Z.K. Zaprianov, Atomic Absorption Spectrometry in Occupational and Environmental Health Practice, CRC Press, Boca Raton, 1983, pp. 189-192. 